\title{
Development Peculiarities of Ethnocultural Environment of the Jewish Autonomous Oblast in the 1920-1950-s
}

\author{
Evelina M. Vladykina* \\ Khabarovsk State Institute of Culture \\ 112 Krasnorechenskaia Str., Khabarovsk, 680045, Russia
}

Received 17.01.2016, received in revised form 22.04.2016, accepted 17.05.2016

\begin{abstract}
Research in such a field as history and culture of Russian Jews is impossible without study of ethnic culture peculiarities encompassing its regional specificity. The present article is dedicated to the analysis of the main stages of the so-called "Birobidzhan Project" in the sphere of ethnocultural community building. Foundation of the Jewish national autonomy in the Far East was of strategic, economic and political significance, satisfying the propaganda need to prove that the Soviet Jewish culture could be successfully developed. The author admits that the technology of the Birobidzhan Project implementation, determined by the forming social and political system, was the factor which did not let its potential unlock to the full.
\end{abstract}

Keywords: ethnocultural environment, Jewish autonomy, resettlement, Yiddish, national selfidentification, sociocultural policy.

DOI: 10.17516/1997-1370-2016-9-6-1277-1286.

Research area: culture studies.

Jewish communities began to appear in the Far East back in the late $19^{\text {th }}$ century. At first, they consisted of recruits, low army ranks, and former convicts, who destined to the farthest boundaries of Russia for various purposes, including isolation from their traditional lifestyle.

At the turn of the $19^{\text {th }}$ and $20^{\text {th }}$ centuries, the Far East Jews lived in specific conditions. They were isolated from the traditional centres of Russian Jewry, hardly competent in the main valueы of Jewish culture, could not use their native language as they wished. However, the Far East Jews strived to preserve their cultural originality, national and religious selfidentification to the best of their capabilities.
They managed to adjust themselves to the local conditions, and, just like other nations, occupied their niche in economy and other spheres of life. According to police reports, back in 1889 there were some developed Jewish communities and functioning synagogues in such cities of the region as Nikolayevsk-onAmur, Khabarovsk, and Vladivostok. The Far East Jews did not suffer of rough governmental or everyday antisemitism. It may be explained by the fact that they did not know the "pale of settlement", did not live in isolation, and their lifestyle did not contrast with that of other local peoples, thereby preserving ethnic and religious tolerance.

(C) Siberian Federal University. All rights reserved

* Corresponding author E-mail address: linavladykina@rambler.ru 
Just like other Jewish communities of preRevolutionary Russia, the Far East Jews were somewhat discriminated in exercising their rights. In the Far East it was impossible to provide them with proper conditions for traditional Jewish education: it was caused by the remoteness of the region from the centres of Jewish education and culture, absence of competent specialists (the closest traditional Talmud Torab school was in Irkutsk). Representatives of Khabarovsk Jewish communities were greatly worried about the traditional education of their children. Multiple petitions to the authorities and requests for permission to open a Jewish school were always rejected. Considering the disinterest of the local authorities to open a traditional Jewish educational institution, the Jews preferred to educate their children at home.

As a result of victory of the Great October Socialist Revolution, it was decided to resolve the issue of political, economic, and national discrimination of Russian Jews. The young government faced the need to solve acute economic and social national problems. In 1927 the Chairman of All-Russian Central Executive Committee stated that the research carried out in various locations in Belarus, Ukraine and Western regions of Russia, "proved the fact of terrifying poverty of great Jewish population, $30-40 \%$ of which has no definite occupation" (Kalinin, 1927). Soviet government intended to solve the problem of the Jewish population distress and set a task to develop a "new person, a bearer of Jewish culture, ethnic in its core and socialistic in its concept".

A task to involve Jews and other ethnicities into a different social and cultural system was set. To fulfil the task, special Jewish sections were formed in the Central Committees and local committees of the Communist party; Jewish Commissariat (EVKOM), a part of Narkomnats (People's Commissariat for National Issues), was organized. The task of EVKOM was to coordinate all spheres of Jewish life according to the new socialistic principles.

In 1924, Committee for the Settlement of Toiling Jews on the Land (KOMZET) and Society for the Settlement of Toiling Jews on the Land (OZET) were organized in order to search for new territories for compact settlement and provision of working Jews with land plots. At first, as the most promising place for resettlement of Jews Crimea was selected. But back in 1927 it was doubted due to the lack of unoccupied land plots and discontent of the local population.

In 1927, Professor Boris Bruk came up with a proposal to send an expedition to the scarcely populated Far Eastern territories to study the possible opportunities for mass resettlement of Jews.

For expedition, the Birsko-Bidzhan District with the territory of over 30 thousand square kilometres was selected. As of 1928, the population of the area was approximately 33 thousand people, which is 0.4 people per square kilometre. At the meeting of the Society for the Settlement of Toiling Jews on the Land held in January 1928, B. Bruk set forward the conclusions he made on the basis of the expedition results. The Professor paid special attention to describing the local population. One of the attendees of the meeting, M. Kats, later said: "Speaking of the local population, Bruk said that it was very small in number, scarcely settled and mainly consisted of new migrants who did not have a feeling of property for the territory yet" (GA EAO.F.3.Op.1.D.14.L.8.). So, the Jewish settlers could hardly affect the economic, social and other interests of the indigenous and other peoples of the district. Moreover, the Far East dwellers had hardly been infected with "the viruses of xenophobia and antisemitism, which could serve as a good base for developing efficient intercultural and interethnic relations". 
It goes without saying that the political aspect of the problem was also taken into account: scarce population of the Far East and its remoteness from the European part of the country could provoke expansionist intents of the neighbouring countries. Together with that, the Kremlin was well aware that the Jewish autonomy in the Far East was alternative to the zionistic idea of founding a Jewish state in Palestine.

From ideological point of view, Soviet authorities faced the task to achieve certain unification of ethnic cultures, sterilizing them of everything that might contradict the new social paradigm. Naturally, such task was easier to fulfil in a region where national self-consciousness was weaker.

In the long run, having summarized all social, political, and other reasons, OZET issued a resolution on the reasonability of resettling Jews to the Far East. The resolution was formulated in the Act of the Presidium of the Central Executive Committee of the USSR dated March 28, 1928 "On assigning a part of territories adjacent to the Amur river near the Bira and the Bidzhan rivers in the Far East Region for intensive settlement of toiling Jews" (GA EAO.F.75.Op.1.D.168.L.1.).

The future settlers were provided with considerable financial support. In multiple cities (Minsk, Gomel, Vitebsk, Mogilev, Moscow, Leningrad) migrant communes and associations were formed. At the same time, in the whole country a wide propaganda campaign was held to involve Jewish population in the resettlement project. KOMZET published many brochures, made propaganda posters, held lectures on the Far East and prospects of its development; a feature film "The Happiness Seekers" was shot, "By the Amur, By the River" play was written and represented.

As soon as in April, 1928, the first echelons carrying 600 settlers arrived at Tikhonkaya Station (future Birobidzhan). The colonization began with multiple challenges caused by lack of finance, severe climate, unsettled household, mess in the project management.

Despite the challenges, new territory development was pretty vigorous. Agriculture was expanding, small industries were founded, forestry and mineral extraction were organized.

In the first years of the Far East Jewish autonomy development one of the primary tasks was to attach the Jewish settlers to their new place of residence. The success of such attachment greatly depended on creating proper conditions for national education and ethnic culture development.

From 1928 to 1935, around 30 thousand Jews arrived in the Far East Region (GA EAO.F.3.Op.1.D.8.L.38.). To satisfy their need for education, the nation-driven school construction was widely launched. The Party and Soviet bodies believed the "jewification" of schools to be one of the most significant processes in developing ethnic culture for all working Jewish population of the Far East. Archive documents as of February 1, 1933, state: "The number of schools is sufficient for the number of children. $97 \%$ of students are educated in their native language. In Birobidzhan District there are 6 Jewish schools with over 300 students (GAHK.F.35.Op.1D.609.L.93.).

Rapid development of Jewish secondary and vocational schools in the Far East Region continued till the late 1930-s. Thus, in 19351936 there were 92 Jewish classes in the Jewish Autonomous Oblast; there were Jewish language courses for Russian schools' students and adults.

The conceptual profile of Jewish education in that period was teaching all subjects including Soviet literature in Yiddish. In accordance with the official cultural requirements, Jewish ethnic schools in the Far East were intended to solve the tasks of "breeding the young generation", "educating a new person, an enthusiast of socialistic choice", educating bearers of Jewish 
culture, "ethnic in its core, socialistic in its concept".

On May 7, 1934, the Presidium of All-Russian Central Executive Committee of the USSR made a decision to reorganize the Birobidzhan District into Jewish Autonomous District, providing it with all the rights established for all constituent autonomous oblasts of Russia by law. Foundation of an ethnic Jewish entity in the Far East evoked a wide response and optimistic hopes for the further development of Russian Jewish community's history and culture.

As a consequence of the decision to form the autonomous oblast, there rose a social movement striving to introduce Yiddish language into the functioning of local state authorities, enterprises, institutions and village councils. According to the resolution issued by the Regional Committee of the All-Union Communist Party of Bolsheviks and oblast executive committee "On starting work of the state and economic organizations and institutions in Yiddish language" dated September 15, 1935, all orders and resolutions, all announcements, document forms and seals were to be drawn up in two languages: Yiddish and Russian. In the same year, Yiddish language courses for state institutions' officers were opened. The attempts to preserve the ethnic language and promote it among the local population, made at the initial stages of the oblast life, demonstrated great desire to educate the Far East Jews the basics of their national spirituality and culture, serving as powerful stimulus for involving new settlers from other territories of the Soviet Union and abroad.

The wish to turn the Jewish autonomy into an ethnic cultural centre worked as a stimulus to develop book culture and library service in the region.

In the area remote from the main centres of Jewish book culture, great efforts were made to organize a library chain to satisfy the needs of migrants from multiple regions and different foreign countries. The wide-scale new territory development was accompanied with expansive cultural, educational campaigns and awarenessbuilding among local and newly arriving population. Libraries proved to be the optimal site for such work. Library service arrangement began in 1929. Starting from that point, mobile libraries and village reading rooms evolved into stationary institutions, keeping books both in Russian and Yiddish. In the process of basic library service development in the new autonomy, the interests of all nationalities were taken into account. Thus, in 1931 "50 per cent of Amurzet library fund were Jewish books, 40 per cent were Russian, 10 per cent were Korean; 60 per cent of books in sovkhoz-kolkhoz library of Volochaevka village were Russian, while 40 per cent were Jewish" (Tutunina, 2002).

One of the most significant oases of Jewish culture in the Far East was the oblast library that opened in Birobidzhan in 1935. There a specialized Jewish literature sector was opened and began its work in 1936, receiving guaranteed free copies of all books published in Yiddish in Moscow, Belarus, and Ukraine. The Jewish literature sector employees did a lot of awarenessbuilding and cultural work, arranging exhibitions of books by Jewish writers, organizing art and literature evenings and other events, dedicated to classical and modern Jewish writers. As of mid-1940-s, the book fund of the oblast library in Yiddish language counted 22762 books, i.e. 36\% of total number of books.

In the 1930-s, the ethnocultural space of the autonomy was greatly boosted by local publisher activity. Periodicals could promptly react to various current events and compensate for the lack of culturally relevant information.

In October 1930 within the framework of the Birobidzhan Project for the first time in the Far East a Jewish newspaper called "The 
Birobidzhaner Stern" was issued. The issue of the first printed newspaper in the Biro-Bidzhan District was initiated by the Secretary of the District Committee of All-Union Communist Party of Bolsheviks Yankel Levin. He assigned a room for typography and ordered type ramps, printing machines and other printing equipment from Harbin Typography of Mr. Rosenzweig. That equipment was used for issuing the first edition of "The Birobidzhaner Stern". In its address to the readers, the editors' board wrote: "The day our newspaper was issued cannot but be a special day for all working Jews" (Sarashevskaia, 2002).

Due to the specificity of newspaper structure, at least a half of the paper was assigned to reports of the current events of the Oblast and the country. Along with that, a series of articles and columns of "The Birobidzhaner Stern" was dedicated to topics unusual for daily papers, such as Jewish ethnic history, literature, and culture. A good illustration is an extensive cycle of articles by journalist and writer G. Rabinkov "From the Russian Jews' History". The author did not just cover the development of Russian Jewry from the ancient to contemporary times, but also considered some issues of ethnic traditions, literature, and culture in general.

Such editing policy of the newspaper was mostly formed by one of its first editors, Heinrich Kazakevich, who was not just a talented person, but also an experienced editor of Jewish papers. Due to the brilliant command of his native language he selected and edited the most interesting materials in Yiddish by himself. Thanks to H. Kazakevich, abstracts from Jewish classics (such as, Sholem Aleichem, Mendele Mocher Sforim etc.) were published in the pages of the paper along with some pieces by local writers.

The works of ethnic Jewish writers was fully covered by the specialized local magazine "The Forpost" (in Yiddish). The first publishing editor of the magazine was Emmanuil Kazakevich (later, a famous Soviet writer). The magazine was dedicated to literature and arts, as well as to social and political issues. It mostly published works by beginner writers and poets from the creative association called "Pigeon's Milk". "Pigeon's Milk" association was founded in Kharkov upon the initiative of E. Kazakevich. Subsequently, almost all members of the association, inspired by romantic ideas, decided to move to Birobidzhan. The mastermind of the association was strongly convinced that, flocking around the magazine, the young authors "in love with Yiddish language and literature" "would be able to create the best and the most beautiful things that may ever be created" (Vospominaniia, 1979). In reality, such representatives of "Pigeon's Milk" as G. Diamant, B. Miller, B. Slutsky pioneered the Far Eastern Jewish literature.

Along with publishing in Yiddish, Jewish radio broadcast was developed. The local radio began its work on February 6, 1935. Broadcast was made both in Russian and in Yiddish. The first editor of Jewish programs was poet Lyubov Wasserman, who moved to Birobidzhan from Palestine in 1934. Jewish radio did not just introduce some significant current events to the listeners, but also presented Jewish ethnic music, poetry, literary heritage of classical and contemporary writers. The Jewish radio had a wide record collection including records of various pieces and songs in Yiddish (by present time, around 140 hours of music records have been preserved) (Sergeeva, 2002). In the first years of Birobidzhan life, Jewish radio broadcast was the most accessible and demanded way of learning Jewish culture in the Far East of Russia.

A powerful catalyst which accelerated the development of national cultural environment in the autonomy was the inflow of Jewish artistic intellectuals. As soon as the first echelons arrived in the Far East, the writers V. Fink, L. Heit, N. Friedman etc. came to the Oblast. This inflow of 
significant Jewish culture bearers did not stop after.

A great contribution into development of the Far Eastern Jewish literature was made by poet B. Olevsky, who arrived in the Far East in the early 30 -s. By that time, he had already written several books in Yiddish. The years the writer spent in the Far East were quite fruitful. He published three poetry books in Yiddish. The books were compiled of mostly landscape and love poems, as well as stories of the heroism of the Far East pioneers.

Jewish prose masters occupied an important place in the literary life of the young autonomy. Convinced that in the Far Eastern borders of the Soviet Union there are all conditions for Jewish national culture development, famous Yiddish language writer D. Bergelson moved to Birobidzhan in the mid 30-s. Here D. Bergelson filled his pieces with new images: the images of migrant Jews, building their new life in challenging and unusual environment.

Creative work of B. Miller is comparative with that of D. Bergelson in its significance. Awarded with a Jewish language and literature teacher qualification, in 1936 the future Far Eastern writer was assigned to work in Birobidzhan, where he spent the rest of his life. The young teacher, inspired by the idea of turning the first Jewish autonomy into an ethnic cultural centre of the country, made a significant contribution into expansion of Jewish cultural space. For many decades, B. Miller was the editor of "The Birobidzhaner Stern" and the leader of the Far Eastern Jewish Writers' Association. His works praising the Far Eastern Region were eagerly published by both local and central Jewish publishing houses.

A separate topic reflected in works by B. Miller is a series of plots associated with development of Jewish cultural and literature life of the Far East. The writer created literary portraits of Der Nister, D. Bergelson, L. Kvitko, G. Diamant, E. Kazakevich and other national poetry and prose authors. B.I. Miller was also the author of several plays represented on the stage of Birobidzhan State Jewish Theatre.

It goes without saying that the newly founded Biro-Bidzhan District was in need for cultural services for Jewish population; for this reason, in summer 1932 a team of students of Theatre College at Moscow State Jewish Theatre went on a tour to Birobidzhan. The tour was such a success that by the middle of 1933 the Committee for Artistic Issues at Council of People's Commissars of RSFSR announced its decision to found Birobidzhan State Jewish Theatre by the efforts of the Theatre College graduates.

The father of the theatre was Emmanuil Kazakevich, who was delegated to make up a company, prepare the first performances and bring the theatre to the Far East. To solve these tasks, he turned to S. Mikhoels, V. Zuskin, and M. Rubinstein. With their assistance, within a year the company presented two Soviet plays in Yiddish and a performance based on short stories by Sholem Aleichem. The company began giving shows as soon as it arrived at Birobidzhan and never saw a lack of audience ever since.

Starting from 1934, the theatre became the epicentre of Jewish cultural life of the Far East. Writers, stage directors, actors, musicians, artists gathered around it. Inside the theatre the creative intellectuals found contact with general public, which was vital for the organization and support of the national cultural space. At the theatre there was a children's studio where children learned music and dance, did performances and concerts.

A separate aspect of the State Jewish Theatre's work was the creation of Russian group of actors in 1939, which presented plays to attract Russian-speaking audience, promoting the interethnic cultural communication. State Jewish 
Theatre existed till December, 1949. During that period, it made over thirty performances based on plays by classic and contemporary Jewish writers. The theatre company introduced the audience to drama pieces by E. Kazakevich, G. Rabinkov, K. Rutsky and other writers. In the theatre there were many talented actors with a good command of scenic speech and Yiddish language. Jewish State Theatre company went on multiple tours around the Far East and beyond. One of the most successful ones was the tour around Ukraine in 1940, which made one of the criticists remark: “ $\ldots$ the tour proved the whole country that Birobidzhan theatre had achieved a high level of artistic maturity (GA EAO.F.148. Op.1.D.1a.L.14.).

A significant element of national cultural space of the autonomy was its music activity. Musical culture of the Far Eastern Jews was remarkable for the diversity of forms and traditions. Musical diversity development was stimulated by the fact that the settlers, who lived in different regions before moving to the Far East, contributed the folk musical culture of Jews from the central parts of Russia, the Ukraine, Belarus, Poland, Argentina, other countries and regions into the common music environment. A distinctive feature of the Far Eastern Jews' folk music was the echo of the ethnic motives in music in the folklore of the ethnos that lived in the same territories with the Jews. Very often in the repertoire of the Far Eastern musicians along with their ethnic music there were Belorussian, Ukrainian and other songs, enriching musical culture and boosting its further development. Many traditional features of ethnic music were typical for the culture of the Far East Jews. First of all, in their music the motives, formed during many centuries, fancily intertwined with some new, adopted elements. In the Far East there were no professional Jewish ensembles or orchestras, but due to the roots the music had had in everyday and holiday culture, due to the position it occupied in the system of traditional education, folk music culture never ceased its development. No wedding and no celebration of the Far East Jews could work without festive ethnic melodies and expressive dance music. Back in the first years of the autonomy's life, a community of Jewish culture bearing professional musicians and composers began developing. M. Epstein was the most famous of all. This composer graduated from Odessa Music and Drama Institute. In 1933 he arrived in the Far East to work in the Jewish Theatre. M. Epstein composed music for multiple theatre performances, wrote over twenty songs, dance melodies and instrumental compositions. Having rich experience of folk music recording and arrangement, the musician bravely used folk melodies in his pieces. The majority of the composer's creations were devoted to the Far East, which became his motherland where he lived till the end of his life. Such pieces by M. Epstein as "The Pioneers" suite, songs "My Earth", "I am Connected with the Fate..." were especially popular among listeners.

Musical culture of Jews has always been tightly intertwined with the celebration culture. At the same time, Jewish holidays play a special role in the process of development of ethnocultural environment. The history of Jewish ethnic holidays may be traced as deep as several thousand years back, proving the thesis of M.M. Bakhtin that holidays are the basic initial form of human culture. Jewish holiday cycle has its specific traits, being based on mythologized history and religious plots. Through their conceptual ritual system, holidays shape up, support and convey some certain collective memory to the new generations, filling real or mythological events of the ancient past with emotional personal experience. Due to the root transformations that happened after the Revolution of 1917, certain changes occurred in the basic of Jewish mentality, 
as well as in the ethnic public consciousness as a whole. It led to rearrangements in many spheres of life and activities of Jews, including Far Eastern Jewish community. The tight connection between Judaism and national Jewish holidays did not match Soviet cultural system. National Jewish holidays, therefore, were unwanted and even seen (by the authorities) as marginal events. The main task of information policy was to destroy the traditional semiotic field and to replace it with a new symbolic system with the priorities and values of Soviet culture. As a result of resettlement policy, in the first years of migration to Birobidzhan thousands of Jews arrived from places where religious traditions and culture, despite the persecution, continued its halflegal existence. Celebration of religious Jewish holidays in the first years of migration to the BiroBidzhan District was first mentioned in the short story by Victor Fint titled "Yom Kippur". Shortly before the Judgement Day, in the autumn of 1928 he went to the Jewish settlement of Waldeim and found himself in a house where there were 9 people sitting in the corners. "The Jews quickly rose, turned their heads to the East and got hold of their talliths. They threw the talliths over their heads, murmuring words of Cabbalistic praise... I don't know what it meant. The talliths were old and torn, patched all over. Who knows, maybe they remembered Jew bashings, those striped shawls, that survived through so many thousand years and even got as far as taiga forest" (Fink, 1930).

Local periodicals, including ethnic ones, could only publish critic articles about Jewish religious holidays. Nevertheless, even such articles eloquently proved that during the whole pre-war period religious holidays were still celebrated. For example, on the Pesach eve, on April 17, 1935, Jewish newspaper "The Birobidzhaner Stern" published lead article calling for all the working people, all kolkhoz workers to fight against the "religious counterrevolution", and to work with double energy in the days of Pesach to celebrate the First of May with high-powered socialistic work. However, the calls did not appeal to everyone, as several days after the same newspaper announced that some Jewish families cooked traditional Pesach foods, toiveled their tableware. Publishing such facts in the front page, the newspaper called for fighting against the holiday phenomenon also because many Jews did not go to work on the days of the holiday. In the first post-war years, with the temporary liberalization, religious holidays came out into the open. On November 25, 1946, Jewish religious community was officially registered in Birobidzhan, and in March 1947 a synagogue was opened. On weekdays, the number of service attendees varied from 80 to 150. On the days of Pesach, Yom Kippur, Rosh Hashana up to 400 people would gather in the synagogue, witnessing the desire of local Jews to follow the traditions of their national holiday cycle. The last burst of religious activity fell on the Jewish holiday of Yom Kippur in 1953. Over 500 people came to the synagogue. According to Birobidzhan historian D.I. Vayserman, after that the community defamation campaign began. Two weeks after during Succos celebration a fight and a night bashing at the synagogue occurred. It was the reason why the Jewish community house was closed (Vayserman, 1999).

Therefore, even under the most unfavourable conditions, the Far East Jews retained the value of their ethnic holidays. The holidays were not necessarily taken as religious. They were a part of the cultural and historical tradition. In the long run, the traditional holiday cycle was crossed out from the lives of many Far Eastern Jews. But it did not happen as a result of assimilation; it was a consequence of deliberate policy run by the government. At the same time, Soviet government believed it assisted the Jewish holiday culture 
development, while this "assistance" was actually a set of measures intended to "secularize" the holiday culture. One of the determining factors of the Jewish public consciousness rearrangement was ideological and educational policy of the state concerning national culture, intended to smoothen the specificity of the people's mentality. The state and party bodies actively supported implantation of new form into the Jewish holiday culture practice, i.e. official, general public culture. Transforming under the influence of compound cultural and historical processes, the holiday culture of the Far East Jews reflects a certain period in the nation's ethnic history. Its consists of traditional elements as well as the elements that emerged later in the postwar years. Jews celebrated general public holidays in the same way other population groups did. At the same time, traditional culture elements were widely used in celebration rituals. An essential condition was cooking exclusively national dishes.

During celebrations, Jewish folk songs and dances were performed, all jokes said were filled with national colours.
Generally, in the first decades of the ethnic territorial-administrative unit in the Far East great efforts (including those of enthusiast Yiddishists) to create a compact ethnocultural space were made. Having settled in the Far East, the Jews managed to assimilate to the new unusual life conditions and retain their national originality. The "Birobidzhan Project", intended to solve social and economic issues of Russian Jewry, proved to be strategically efficient. However, the project implementation technology, determined by the forming social and political system, did not let the project live it up to its potential. In the process of further implementation of the "Birobidzhan Project", the everyday life, traditions, and culture of the Far East Jews were severely demolished. As a result of the state policy determined to emasculate the specific ethnic core of Jewish culture, the Far East Jews began forgetting their national traditions and customs, rejecting their mother tongue and got soon involved in the assimilation process.

\section{References}

Vayserman, D.I. (1999) Birobidzhan: mechty i tragediia [Birobidzhan: Dreams and Tragedy]. Khabarovsk, Riotip, 1999, 504 p.

Vospominaniia o E. Kazakeviche [Memories of E. Kazakevich] (1979). Moscow, p. 77.

GA EAO.F.148.Op.1.D.1a.L.14.

GA EAO.F.3.Op.1.D.14.L.8.

GA EAO.F.3.Op.1.D.8.L.38.

GA EAO.F.75.Op.1.D.168.L.1.

GAHK.F.35.Op.1D.609.L.93.

Kalinin, M.I. (1927) Evreyskiy vopros [Jewish Issue]. Kharkov, Proletariy, p. 8.

Sarashevskaia, E.I. (2002) Gazeta «Birobidzhaner Shtern» kak sredstvo propagandy evreyskoy kul'tury na territorii EAO, Rossii i za rubezhom [Newspaper "The Birobidzhaner Stern" As a Means of Jewish Culture Propaganda in the Territory of the JAO, Russia And Abroad], In Birobidzhanskiy opyt evreyskogo natsional'nogo vozrozhdeniia. Materialy gorodskoy nauchno-prakticheskoy konferentsii [Birobidzhan Experience of Jewish National Renaissance. Proceedings of the Municipal Scientific and Practical Conference]. Birobidzhan, Freyd, p. 78.

Sergeeva, A.M. (2002) 67 let v efire na mame-loshn [67 Years on Air in Mama-Loshn], In Birobidzhanskiy opyt evreyskogo natsional'nogo vozrozhdeniia. Materialy gorodskoy nauchno- 
prakticheskoy konferentsii [Birobidzhan Experience of Jewish National Renaissance. Proceedings of the Municipal Scientific and Practical Conference]. Birobidzhan, Freyd, p. 62

Tutunina, R.P. (2002) Istoricheskie stranichki: pervye ochagi natsional'noy kul'tury na territorii EAO [Historic Pages: First Ethnic Culture Oases In JAO], In Birobidzhanskiy opyt evreyskogo natsional'nogo vozrozhdeniia. Materialy gorodskoy nauchno-prakticheskoy konferentsii [Birobidzhan Experience of Jewish National Renaissance. Proceedings of the Municipal Scientific and Practical Conference]. Birobidzhan, Freyd, p. 59.

Fink, V.G. (1930) Yom-Kipur [Yom Kippur]. Moscow, B.I., p. 19.

\section{Специфика формирования этнокультурной среды Еврейской автономной области в 1920 - 1950-е гг.}

Э.М. Владыкина

Хабаровский государственный институт культуры Россия, 680045, Хабаровск, ул. Краснореченская, 112

Исследование такого пласта, как история и культура российских евреев, невозможно без выявления особенностей национальной культуры с учетом её региональной специифики. Статья посвящчена анализу основных этапов реализации «Биробиджанского проекта» 6 сфере этнокультурного строительства. Создание еврейской национальной автономии на Дальнем Востоке имело стратегическое, экономическое и политическое значение, отвечало пропагандистским целям, призванным показать, что развитие советской еврейской культуры может быть успешным. Автор признает, что технология осуществления «Биробиджанского проекта», определявшаяся формирующейся соичильно-политической системой, не позволила его потенциалу реализоваться в полной мере.

Ключевые слова: этнокультурная среда, еврейская автономия, переселение, идиш, национальная самоидентификация, соџиокультурная политика.

Научная специальность: 24.00.00 - культурология. 